\title{
Title: Variation in SARS-CoV-2 bioaerosol production in exhaled breath
}

3 Authors: Renu Verma ${ }^{1}$, Eugene $\mathrm{Kim}^{1}$, Nicholas Degner ${ }^{1}$, Katharine S. Walter ${ }^{1}$, Upinder

4 Singh $^{1,2}$, Jason R. Andrews ${ }^{1}$

Author Affiliations

1. Division of Infectious Diseases and Geographic Medicine, Stanford University School of Medicine, Stanford, CA, USA

2. Dept of Microbiology and Immunology Stanford University School of Medicine, Stanford, CA, USA

16 Word Count: 1365

17 Tables: 2

18 Figures: 2

19 Reference: 13

20 Keywords: COVID-19, infectiousness, exhaled breath, gelatin masks, whole genome

21 sequencing

\section{Correspondence:}

24 Jason Andrews, MD

25 Division of Infectious Diseases and Geographic Medicine

26 Stanford University School of Medicine

27 Biomedical Innovations Building, Rm 3458

28240 Pasteur Dr.

29 Stanford, CA 94305

30 Email: jandr@stanford.edu

31 Phone: +1 6504972679 
medRxiv preprint doi: https://doi.org/10.1101/2021.07.20.21260892; this version posted July 22, 2021. The copyright holder for this preprint (which was not certified by peer review) is the author/funder, who has granted medRxiv a license to display the preprint in perpetuity. All rights reserved. No reuse allowed without permission.

\section{Abstract}

34 Using face mask bioaerosol sampling, we found substantial variation between individuals in

35 SARS-CoV-2 copies exhaled over a 15 -minute period, which moderately correlated with nasal

36 swab viral load. Talking was associated with a median of $2 \log _{10}$ greater exhaled viral copies.

37 Exposure varies substantially between individuals but may be risk stratified by nasal swab viral

38 load and whether the exposure involved conversation. 
medRxiv preprint doi: https://doi.org/10.1101/2021.07.20.21260892; this version posted July 22, 2021. The copyright holder for this preprint (which was not certified by peer review) is the author/funder, who has granted medRxiv a license to display the preprint in perpetuity.

All rights reserved. No reuse allowed without permission.

\section{Background}

41 The Centers for Disease Control and Prevention (CDC) guidelines define a close contact as an

42 individual who spent at least 15 minutes, over a 24-hour period, within 2 meters of an individual

43 with COVID-19 $(1,2)$. This definition has been widely used to inform contact investigations in

44 community as well as in healthcare settings (3) based on a premise of average risk, though the

45 empirical basis for this specific time window is limited. We hypothesized that individual

46 characteristics and actions- such as talking may also affect the overall bioaerosol shedding and

47 might impact exposure risk over this time window.

49 Potential variation in SARS-CoV-2 bioaerosol production has been modeled by combining

50 estimates of concentrations in airway swabs with data on total droplet production volume, but

51 direct measurements of variation in exhaled SARS-CoV-2 abundance have been lacking (4).

52 This may be in part due to lack of a flexible bioaerosol sampling tool which allows quantitative

53 assessment of the determinants of bioaerosol variation within individuals. Face mask sampling is

54 a convenient, low-cost bioaerosol sampling method which has been proven effective in detecting

55 viruses including influenza and SARS-CoV-2 (5-7). However, these preliminary studies reported

56 marginal sensitivities (38\% to $40 \%$ ) and additional data are required on the sensitivity of mask

57 sampling. Additionally, mask sampling has not been explored as a tool to quantitatively assess

58 the determinants of viral shedding. With improved sensitivity and high sample recovery, mask

59 sampling can be used as an alternate sample source to study infectiousness. In this study, we

60 developed a mask sampling tool to quantify and sequence SARS-CoV-2 from exhaled breath and

61 used this to investigate the impact of speech and individual characteristics on viral shedding. 
medRxiv preprint doi: https://doi.org/10.1101/2021.07.20.21260892; this version posted July 22, 2021. The copyright holder for this preprint (which was not certified by peer review) is the author/funder, who has granted medRxiv a license to display the preprint in perpetuity.

All rights reserved. No reuse allowed without permission.

\section{The study}

64 We recruited COVID-19 positive individuals from Stanford Hospital, including inpatient wards

65 and an outpatient clinical trials unit, between September 2020 and March 2021 (Table 1). All

66 participants were $>18$ years of age and provided informed consent. The study was approved by

67 the Stanford IRB (\#57686). We fitted N95 masks with a 47mm Petri dish (Fisherbrand)

68 containing gelatine membrane filter (Sartorius) (Supplementary figure 1). We collected 141

69 mask samples from 97 individuals recruited in two groups (A \& B). Group A (n=53 wore a mask

70 for 30 minutes and was allowed to talk (or not) without further prompting. Group B (n=44) was

71 instructed to wear two masks for 15 minutes each. For the first mask, they were instructed not to

72 talk, while for the second mask they were asked to talk with the interviewer or a family member.

74 The filter was dissolved in $1 \mathrm{ml}$ of Primestore MTM (Longhorn diagnostics) media and RNA was

75 extracted using MagMAX ${ }^{\mathrm{TM}}$ Ultra Kit (Applied Biosystems). SARS-CoV-2 was detected with

76 RT-qPCR using the CDC qualified N-gene assays and human RNaseP was used as a quality

77 control (8). RNA recovery and limit of detection (LoD) from mask and swab were compared by

78 spiking serially diluted SARS-CoV-2 synthetic RNA. SARS-CoV-2 genome was sequenced in-

79 house from 21 exhaled breath and 14 paired nasal swab samples using ARTIC v3 Illumina

80 sequencing protocol described previously (9) (Supplementary methods). In paired masks from

81 the same individual, we compared SARS-CoV-2 detection dichotomously using McNemar's test

82 and quantitatively using Wilcoxon sign rank tests with continuity correction. We used the

83 nfcore/viralrecon bioinformatic pipeline containerized on Nextflow to perform variant calling

84 and generate consensus sequences from raw reads (10). We used the R package ape to measure

85 pairwise SNP distance between consensus sequences (11). 
medRxiv preprint doi: https://doi.org/10.1101/2021.07.20.21260892; this version posted July 22, 2021. The copyright holder for this preprint (which was not certified by peer review) is the author/funder, who has granted medRxiv a license to display the preprint in perpetuity.

All rights reserved. No reuse allowed without permission.

SARS-CoV-2 was detected in exhaled breath from $71 \%$ (69/97) of participants, who were

87 sampled at a median of 4 days (IQR: 3-5.25) from symptom onset and 2 days (IQR: 2-3) from

88 first positive SARS-CoV-2 test. Among 77 patients with a nasal swab collected at the same

89 encounter, $67(87 \%)$ had SARS-CoV-2 positive nasal swabs. Mask samples were positive in

$9074.6 \%(50 / 67)$ of participants with positive swabs and 1/10 (10\%) participants with negative

91 swabs. Viral copy numbers in masks collected for 30 minutes (Pearson's $r=0.76, p<0.001$ ) and

92 for 15 minutes (Pearson's $\mathrm{r}=0.58, \mathrm{p}<0.001$ ) talking were moderately correlated with paired

93 nasal swabs (Figure 1 A). In group B ( $n=44)$, compared with mask samples collected while

94 participants were not talking, mask samples collected while talking were more likely to be

95 positive $(59.0 \%$ vs $42.1 \%$; $\mathrm{p}=0.061)$ and viral copies were significantly higher (median $\log _{10}$

96 difference: 2, IQR: 0, 3.6; $\mathrm{p}<0.001$ ). Over 15 minutes of collection, total viral copies captured by

97 masks varied substantially, ranging from 0 to $5.0 \times 10^{6}$ copies (median $=393$ ) while talking to 0

98 to $8.4 \times 10^{4}$ copies (median= 0 ) while not talking (Figure 1B) (Table 2).

99

100 We further investigated the effect of age, sex and presence of symptoms with the number of viral

101 particles released in exhaled breath. Viral load (Pearson's r=0.57; $\mathrm{p}=0.001$ ) and RNaseP

102 abundance $(\mathrm{p}=0.04)$ in exhaled breath were moderately correlated with greater age in the 15 -

103 minute talking group. Overall, duration of symptoms $(\mathrm{p}=0.625)$, days from first positive SARS-

104 CoV-2 test $(\mathrm{p}=0.812)$, and Human RNAseP copies $(\mathrm{p}=0.227)$ were not predictive of viral copies

105 collected in masks. Mask positivity in inpatients 11/22 (50\%) was significantly lower compared

106 with outpatients 58/75 (77\%) (p=0.04). 
medRxiv preprint doi: https://doi.org/10.1101/2021.07.20.21260892; this version posted July 22, 2021. The copyright holder for this preprint (which was not certified by peer review) is the author/funder, who has granted medRxiv a license to display the preprint in perpetuity.

All rights reserved. No reuse allowed without permission.

108 To assess the quality of RNA extracted from the mask filters and explore the potential for mask

109 sampling to be used for genomic surveillance, we sequenced the exhaled breath samples. The

110 majority $71 \%(15 / 21)$ of all mask samples met our targets for sequencing coverage depth (100X)

111 and width (>90\% of the genome with $>10 \mathrm{X}$ coverage) targets (Figure 2A). Median coverage

112 depth was correlated with viral load, (Pearson's $r=0.65, \mathrm{p}<0.001)$ (Figure 2B). Phylogenetic

113 (Pango) lineages assigned with sequences from mask samples were concordant with lineages

114 assigned with sequences from nasopharyngeal swabs in all (14/14) paired samples meeting our

115 coverage thresholds, including reported variants of concern (Supplementary Table 1).

116 
medRxiv preprint doi: https://doi.org/10.1101/2021.07.20.21260892; this version posted July 22, 2021. The copyright holder for this preprint (which was not certified by peer review) is the author/funder, who has granted medRxiv a license to display the preprint in perpetuity.

All rights reserved. No reuse allowed without permission.

\section{Conclusions}

118 Epidemiologic data provides strong evidence for transmission of COVID-19 through breathing

119 or talking $(12,13)$. Asadi et al observed that a small proportion of individuals consistently

120 released an order of magnitude greater aerosols than their peers (4). However, quantitative

121 assessment of SARS-CoV-2 bioaerosol production and its determinants has been lacking.

122 Leveraging an easy-to-use mask sampling tool, we measured interindividual variation in SARS-

123 CoV-2 bioaerosol production and quantified the contribution of speech. We further demonstrated

124 the potential application of bioaerosol sampling for whole genome sequencing of respiratory

125 pathogens to study transmission and variant detection.

127 Overall, we observed $71 \%$ SARS-CoV-2 RNA positivity in mask samples which was

128 significantly higher than the previously reported studies (38\% to 40\%) which used different

129 sampling strategies $(6,7)$. We found that there are orders of magnitude variation in the bioaerosol

130 across a 15-minute period between individuals, which is significantly affected by speech and

131 higher age. Our findings suggest that while it is challenging to define a specific threshold for risk

132 based on cumulative exposure time (1), evaluating additional factors such as speech and

133 physiological characteristics of the infected individual during exposure could be valuable in

134 defining exposure risk. This was recently reflected in a report released by the CDC where they

135 observed SARS-CoV-2 transmission in the National Football League after $<15$ minutes of

136 cumulative interaction, leading to a revised definition of a high-risk contact that evaluated mask

137 use and ventilation in addition to duration and proximity of interaction (2). The results of this

138 study should be interpreted with the context of several limitations. RT-qPCR cannot distinguish

139 replication-competent viruses from RNA. Our mask bioaerosol sampler captures all sizes of 
medRxiv preprint doi: https://doi.org/10.1101/2021.07.20.21260892; this version posted July 22, 2021. The copyright holder for this preprint (which was not certified by peer review) is the author/funder, who has granted medRxiv a license to display the preprint in perpetuity.

All rights reserved. No reuse allowed without permission.

140 respiratory particles, from large to small droplets, which likely carry very different risks of

141 infection, further dependent on proximity and ventilation. Further studies with aerodynamic

142 particle sizers could further quantify the size distribution of SARS-CoV-2 containing bioaerosols

143 and its determinants. Finally, to avoid discomfort among patients with higher oxygen

144 requirements, we only recruited patients with mild symptoms.

146 In summary, we developed a mask sampling tool to quantify and sequence SARS-CoV-2 from

147 exhaled breath and used our method to provide quantitative evidence on the impact of speech

148 and interindividual variation on SARS-CoV-2 shedding in bioaerosol. We found that nasal swab

149 viral load moderately correlates with bioaerosol production and that talking substantially

150 amplifies exposure risk, findings which may inform assessment and risk stratification of

151 exposures. Mask tool developed here can be further validated for its application to investigate the

152 genomes of other respiratory pathogens. 
medRxiv preprint doi: https://doi.org/10.1101/2021.07.20.21260892; this version posted July 22, 2021. The copyright holder for this preprint

(which was not certified by peer review) is the author/funder, who has granted medRxiv a license to display the preprint in perpetuity.

All rights reserved. No reuse allowed without permission.

\section{Biographical Sketch}

155 Dr. Verma is a molecular microbiologist at the Division of Infectious Diseases and Geographic

156 Medicine, Stanford University School of Medicine, CA, USA. Her primary research interests

157 include development of low-cost point-of-care diagnostics for infectious diseases.

\section{Acknowledgments}

160 We thank the study teams and participants from the Covid-19 Clinical Trials Research Unit at

161 Stanford University.

162

\section{Potential conflicts of Interest}

164 We declare that we have no conflicts of interest for this work.

\section{Financial support}

167 This study was supported by an anonymous donation to the Stanford University School of

168 Medicine. The donors had no role in data analysis, interpretation, or decision to publish the

169 findings. 
medRxiv preprint doi: https://doi.org/10.1101/2021.07.20.21260892; this version posted July 22, 2021. The copyright holder for this preprint (which was not certified by peer review) is the author/funder, who has granted medRxiv a license to display the preprint in perpetuity.

170

171

172

173

174

175

176

177

178

179

180

181

182

183

\section{References}

1. Pringle JC, Leikauskas J, Ransom-Kelley S, Webster B, Santos S, Fox H, Marcoux S, et al. COVID-19 in a Correctional Facility Employee Following Multiple Brief Exposures to Persons with COVID-19 - Vermont, July-August 2020. MMWR Morb Mortal Wkly Rep. 2020 Oct 30;69(43):1569-1570.

2. Mack C, Wasserman E, Perrine C, MacNeil A, Anderson D, Myers E et al. Implementation and Evolution of Mitigation Measures, Testing, and Contact Tracing in the National Football League, August 9-November 21, 2020. MMWR Morb Mortal Wkly Rep. January 29, 2021 / 70(4);130-135.

3. Centers for Disease Control and Prevention. Interim Infection Prevention and Control Recommendations for Healthcare Personnel During the Coronavirus Disease 2019 (COVID-19) Pandemic. https://www.cdc.gov/coronavirus/2019-ncov/hcp/infectioncontrolrecommendations.html.

4. Asadi S, Wexler AS, Cappa CD, Barreda S, Bouvier NM, Ristenpart WD. Aerosol emission and superemission during human speech increase with voice loudness. Sci Rep. 2019 Feb 20;9(1):2348.

5. Huynh KN, Oliver BG, Stelzer S, Rawlinson WD, Tovey ER. A new method for sampling and detection of exhaled respiratory virus aerosols. Clin Infect Dis. 2008 Jan 1;46(1):93-5.

6. Williams CM, Pan D, Decker J, Wisniewska A, Fletcher E, Sze S, Assadi S, Haigh R, Abdulwhhab M, Bird P, Holmes CW, Al-Taie A, Saleem B, Pan J, Garton NJ, Pareek M, Barer MR. Exhaled SARS-CoV-2 quantified by face-mask sampling in hospitalised patients with COVID-19. J Infect. 2021 Jun;82(6):253-259. 
medRxiv preprint doi: https://doi.org/10.1101/2021.07.20.21260892; this version posted July 22, 2021. The copyright holder for this preprint (which was not certified by peer review) is the author/funder, who has granted medRxiv a license to display the preprint in perpetuity.

All rights reserved. No reuse allowed without permission.

7. Sriraman K, Shaikh A, Parikh S, Udupa S, Chatterjee N, Shastri J, Mistry N. Noninvasive adapted N-95 mask sampling captures variation in viral particles expelled by COVID-19 patients: Implications in understanding SARS-CoV2 transmission. PLoS One. 2021 Apr 12;16(4):e0249525.

8. CDC. 2019-Novel Coronavirus (2019-nCoV) Real-time RT-PCR Primers and Probes. probes.html (2020).

9. Farr B, Rajan D, Betteridge E, Shirley L, Quail M, Park N et al. COVID-19 ARTIC v3 Illumina library construction and sequencing protocol V.5. dx.doi.org/10.17504/protocols.io.bgxjjxkn

10. Ewels PA, Peltzer A, Fillinger S, Patel H, Alneberg J, Wilm A, et al. The nf-core framework for community-curated bioinformatics pipelines. Nat Biotechnol. 2020 Mar;38(3):276-278. doi: 10.1038/s41587-020-0439-x. PMID: 32055031.

11. Paradis E, Schliep K. ape 5.0: an environment for modern phylogenetics and evolutionary analyses in R. Bioinformatics. 2019 Feb 1;35(3):526-528. Rate Following Exposure at a Choir Practice - Skagit County, Washington, March 2020. MMWR Morb Mortal Wkly Rep. 2020 May 15;69(19):606-610. CoV-2 attack rates following exposure during singing events in the Netherlands, SeptemberOctober medRxiv. doi: https://doi.org/10.1101/2021.03.30.21253126 
medRxiv preprint doi: https://doi.org/10.1101/2021.07.20.21260892; this version posted July 22, 2021. The copyright holder for this preprint (which was not certified by peer review) is the author/funder, who has granted medRxiv a license to display the preprint in perpetuity.

All rights reserved. No reuse allowed without permission.

\section{Table 1: Study population characteristics}

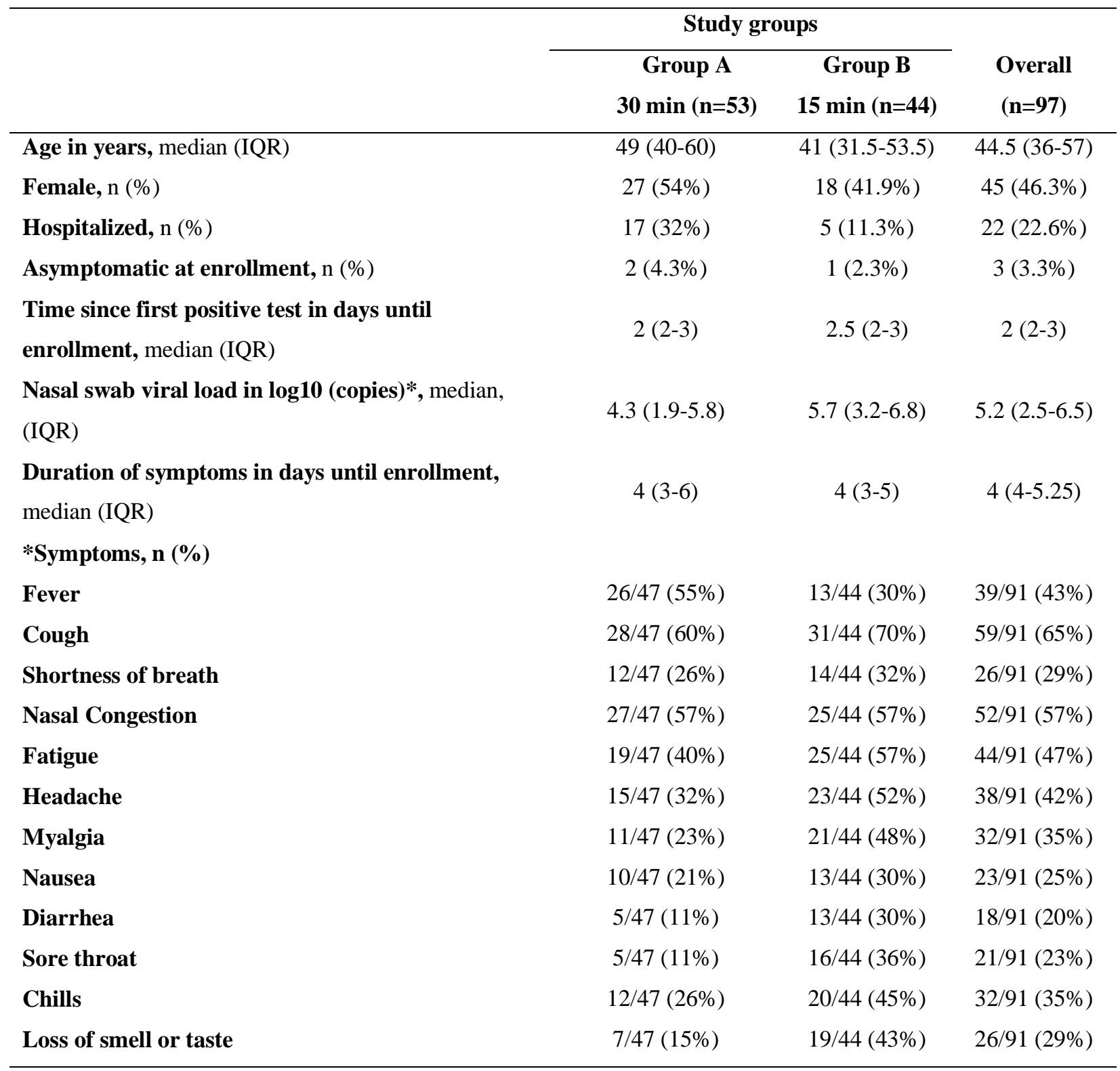

*Symptom data was available for 91 patients 
medRxiv preprint doi: https://doi.org/10.1101/2021.07.20.21260892; this version posted July 22, 2021. The copyright holder for this preprint (which was not certified by peer review) is the author/funder, who has granted medRxiv a license to display the preprint in perpetuity.

All rights reserved. No reuse allowed without permission.

219 Table 2: SARS-CoV-2 $\mathbf{N}$ gene copies and RNaseP cycle threshold $(\mathrm{Ct})$ values detected in 220 paired samples from $\mathbf{4 4}$ individuals while talking or not talking for 15 minutes.

\begin{tabular}{lccc}
\hline & Talking & No talking & P-value \\
\hline N-gene copies/mask*, median (range) & $393\left(0-5.1 \times 10^{6}\right)$ & $0\left(0-8.4 \times 10^{4}\right)$ & 0.028 \\
RNAseP Ct, median for Ct (range) & $32.2(24.9-\mathrm{ND})$ & $34.6(22.2-\mathrm{ND})$ & $<0.001$ \\
\hline
\end{tabular}

*Averaged copy numbers for N1 and N2 assays

$\dagger$ Wilcoxon signed rank test with continuity correction used to test significance

ND: Not detected 
medRxiv preprint doi: https://doi.org/10.1101/2021.07.20.21260892; this version posted July 22, 2021. The copyright holder for this preprint (which was not certified by peer review) is the author/funder, who has granted medRxiv a license to display the preprint in perpetuity.

\section{Figures}

Figure 1. Correlation between mask and nasal swab viral copies. (A) Viral copy numbers detected in masks and nasal swabs were moderately correlated in group A (30 minutes sampling without instructions; blue, $\mathrm{n}=33$ ) and group B (15 minutes sampling; red, $\mathrm{n}=44)$ talking cohort. (B) Total number of viral copies detected per mask sample in talking and no talking group. The

231 viral copies were detected using SARS-CoV-2 specific N1 and N2 probes. Viral copies were 232 quantified on standard curve derived from N-gene containing pET21b+ plasmid.

Figure 2. Whole genome sequencing coverage comparison between mask and swab. (A) The majority $71.4 \%(15 / 21)$ of all mask samples, including $62.5 \%(5 / 8)$ mask, $50.0 \%$ mask no

236 talking, and 88.9\% (8/9) mask talking samples, met our targets for sequencing coverage depth

237 (100X) and width (>90\% of the genome with $>10 \mathrm{X}$ coverage). (B) Median coverage depth was 238 correlated with viral load $(\mathrm{r}=0.65, \mathrm{p}<0.001)$

240 Supplementary Figure 1. (1) The assembly of the gelatin filter mask. The N-95 mask (i) is used 241 as a base, to which a $47 \mathrm{~mm}$ petri dish (ii) is attached. A $47 \mathrm{~mm}$ gelatin filter (iii) is placed inside, 242 and the petri dish lid (iv) is used to secure the filter until collection. (2) The assembled mask. (B)

243 Before exhaled breath sampling, the limit of detection (LoD) of SARS-CoV-2 RNA recovered

244 from the gelatine filter using our sample processing protocol was compared with spiked RNA in

245 nasal swabs. Masks and nasal swabs from healthy volunteers were spiked with serially diluted 246 SARS CoV-2 RNA $\left(10^{6}-10^{1}\right)$ in duplicates. Viral RNA was detected with as low as 100 247 copies/filter in both duplicates in mask and swab. Blue dots and triangles represent copies 248 determined by the N1 and N2 assays respectively from mask. Orange dots and triangles represent 
medRxiv preprint doi: https://doi.org/10.1101/2021.07.20.21260892; this version posted July 22, 2021. The copyright holder for this preprint (which was not certified by peer review) is the author/funder, who has granted medRxiv a license to display the preprint in perpetuity.

All rights reserved. No reuse allowed without permission.

249 copies determined by the N1 and N2 assays respectively from swab. The black, diagonal dot-

250 dashed line represents the regression expected when the viral copies recovered are equal to the

251 viral copies spiked. The vertical dotted line indicates the limit of detection of the assay. 


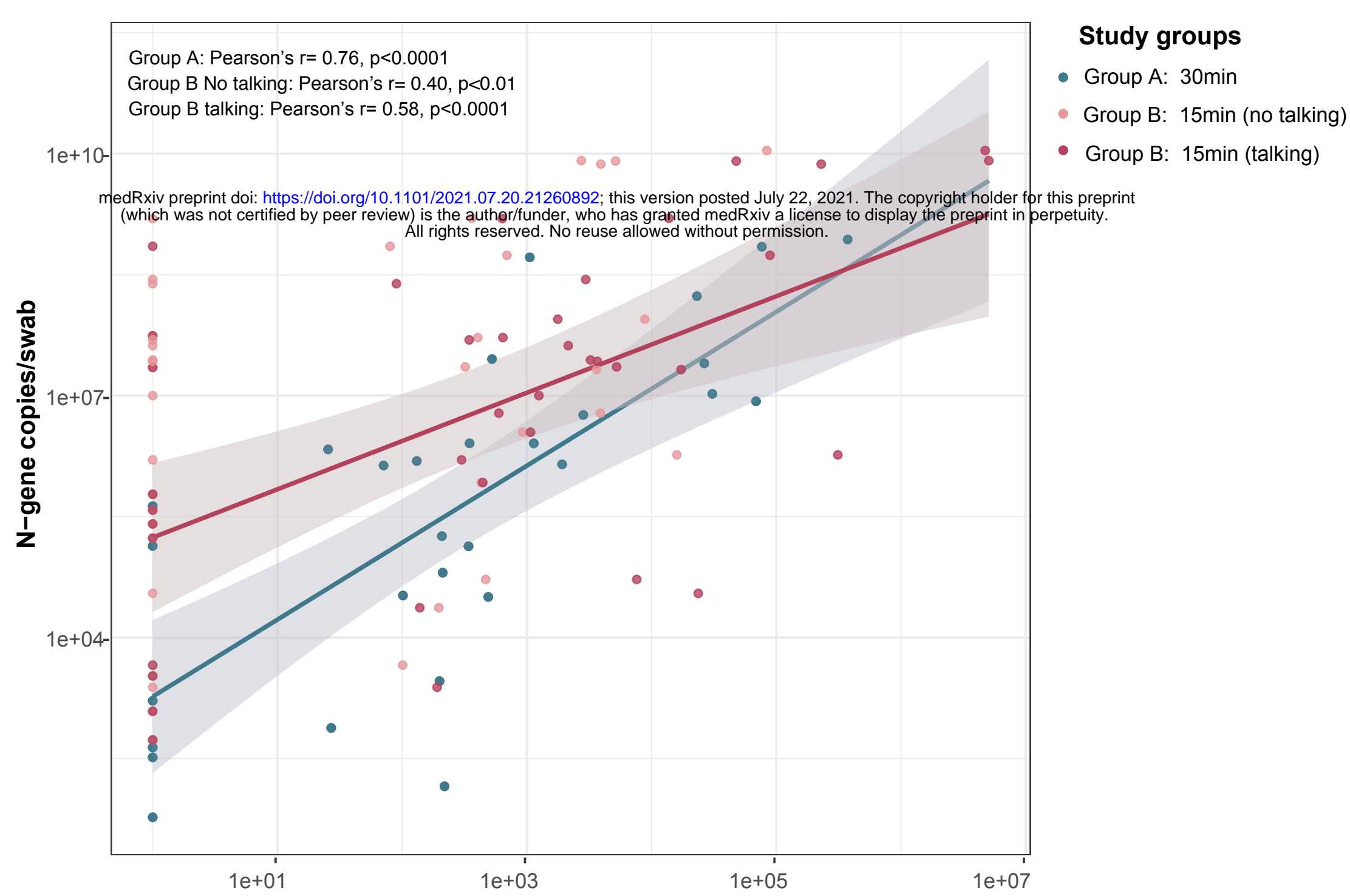

$\mathrm{N}$-gene copies/mask

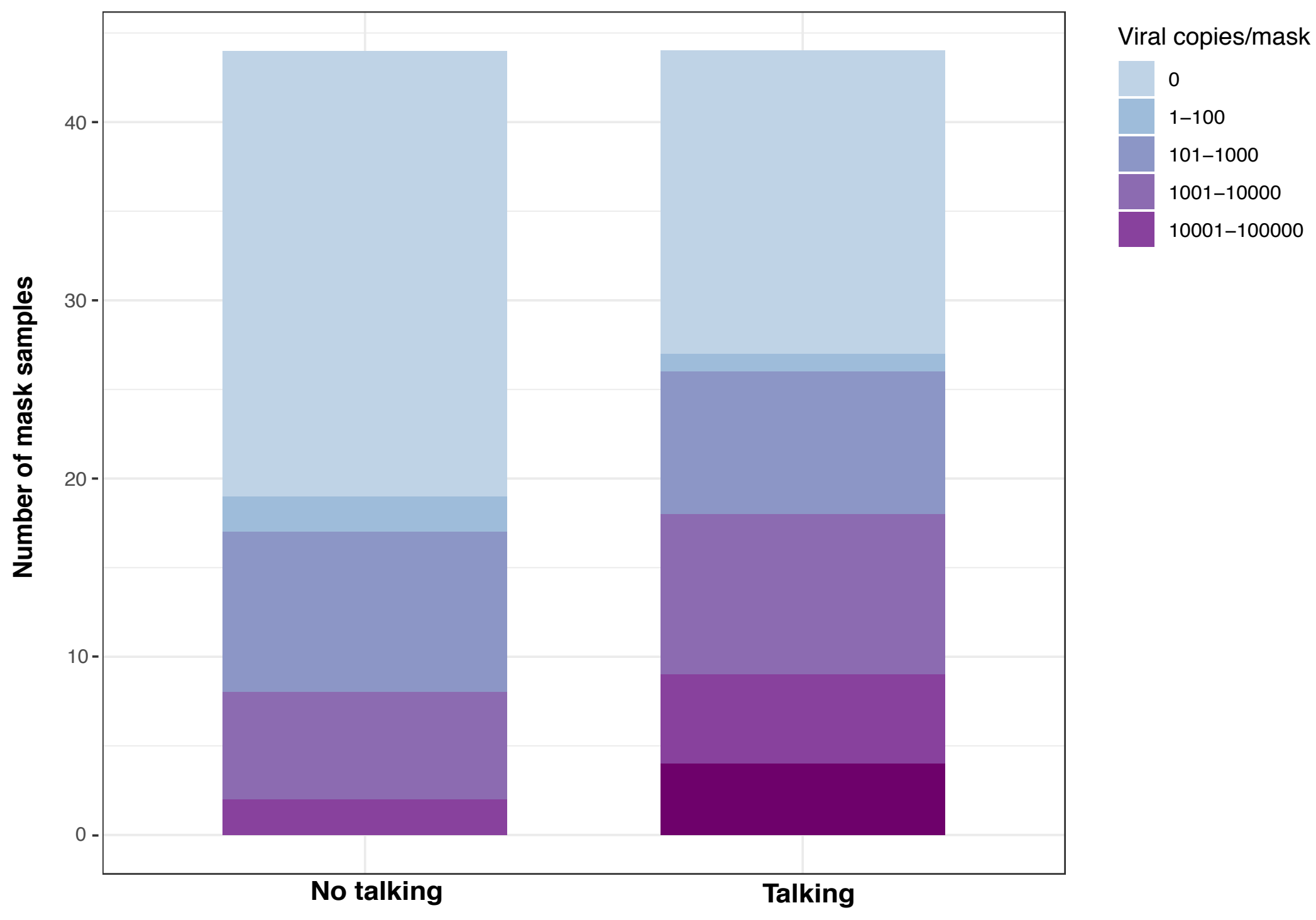


(A)

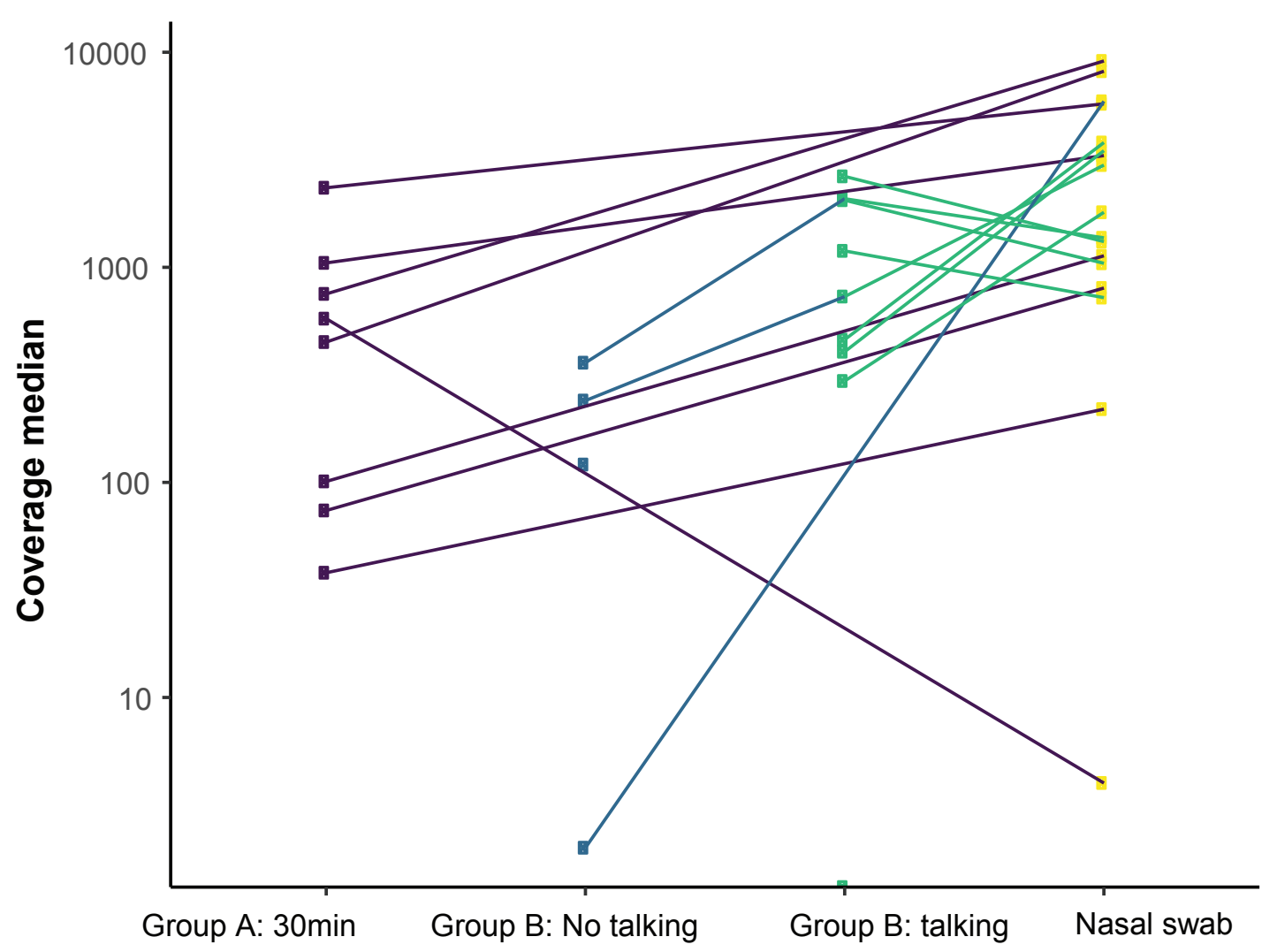

\section{Sample type}

(B)

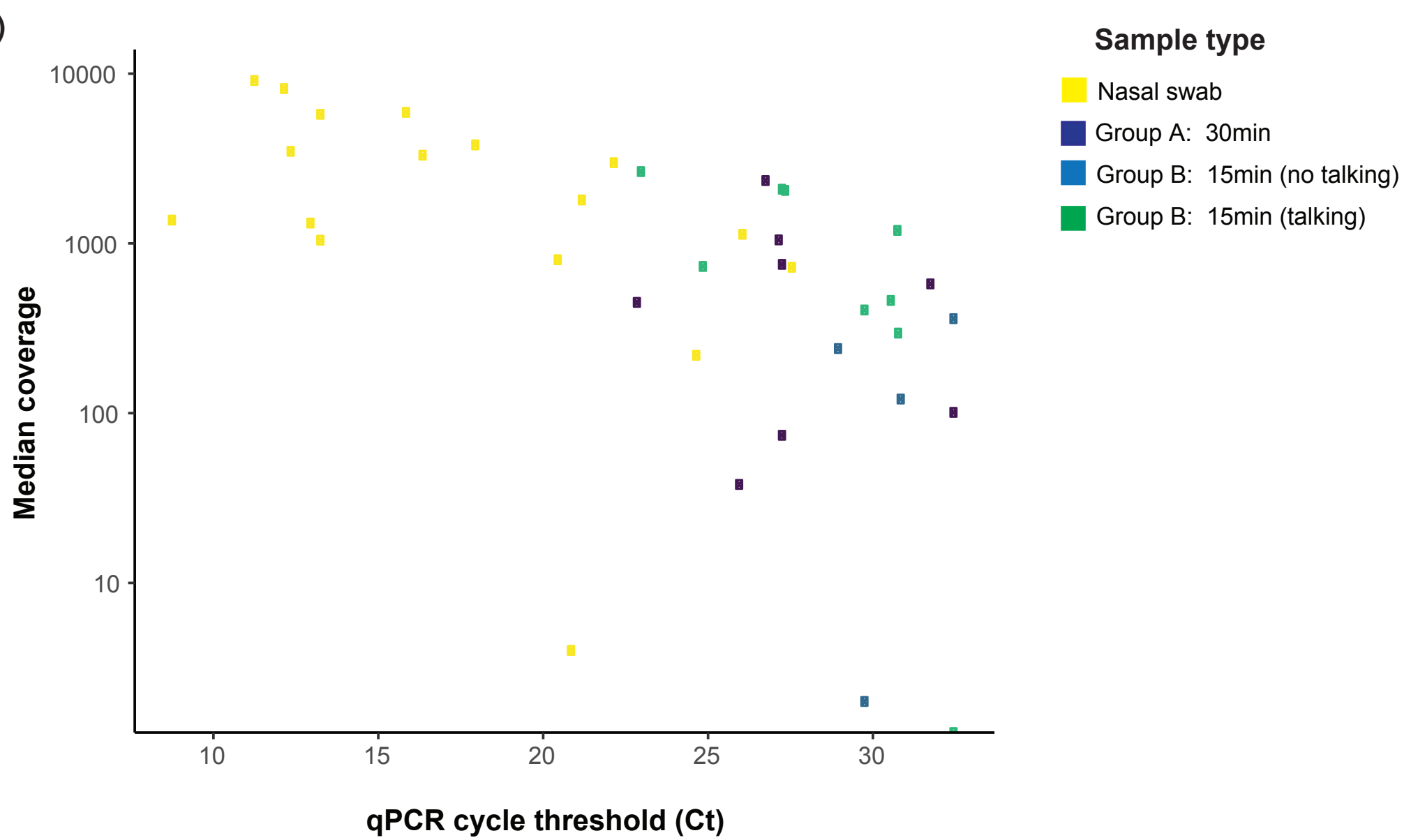

\section{Sample type}

Nasal swab

- Group A: 30min

— Group B: 15min (no talking)

- - Group B: 15min (talking) 
(A)

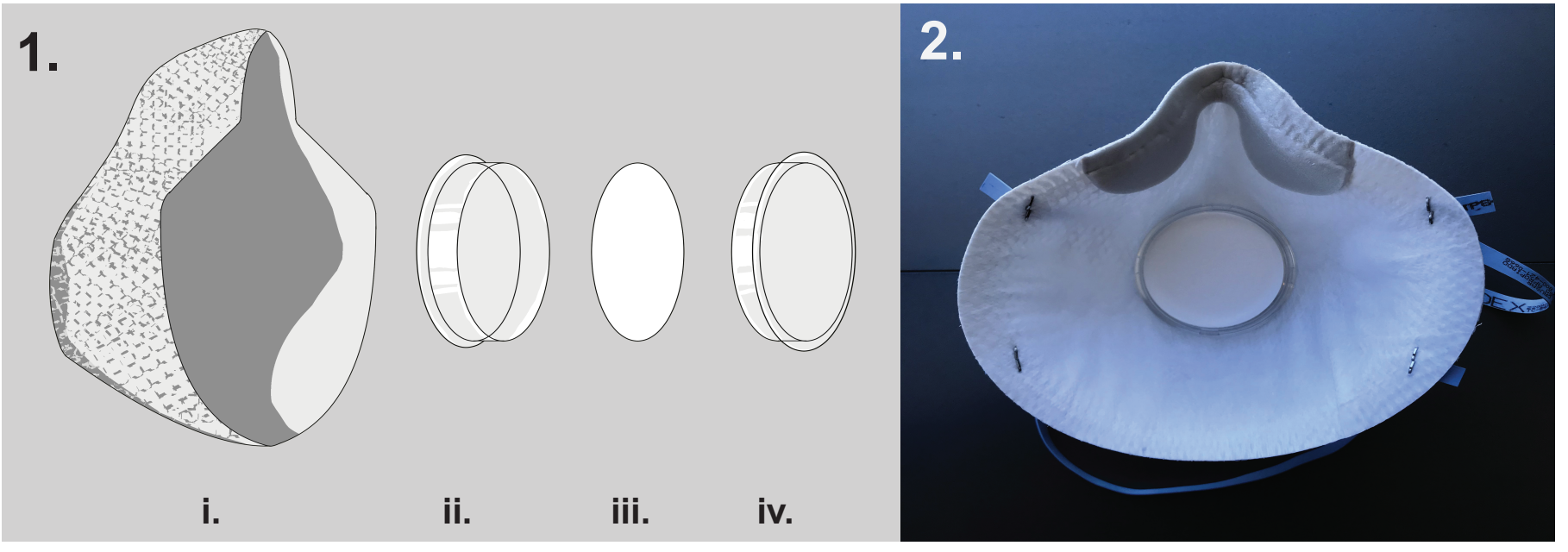

(B)

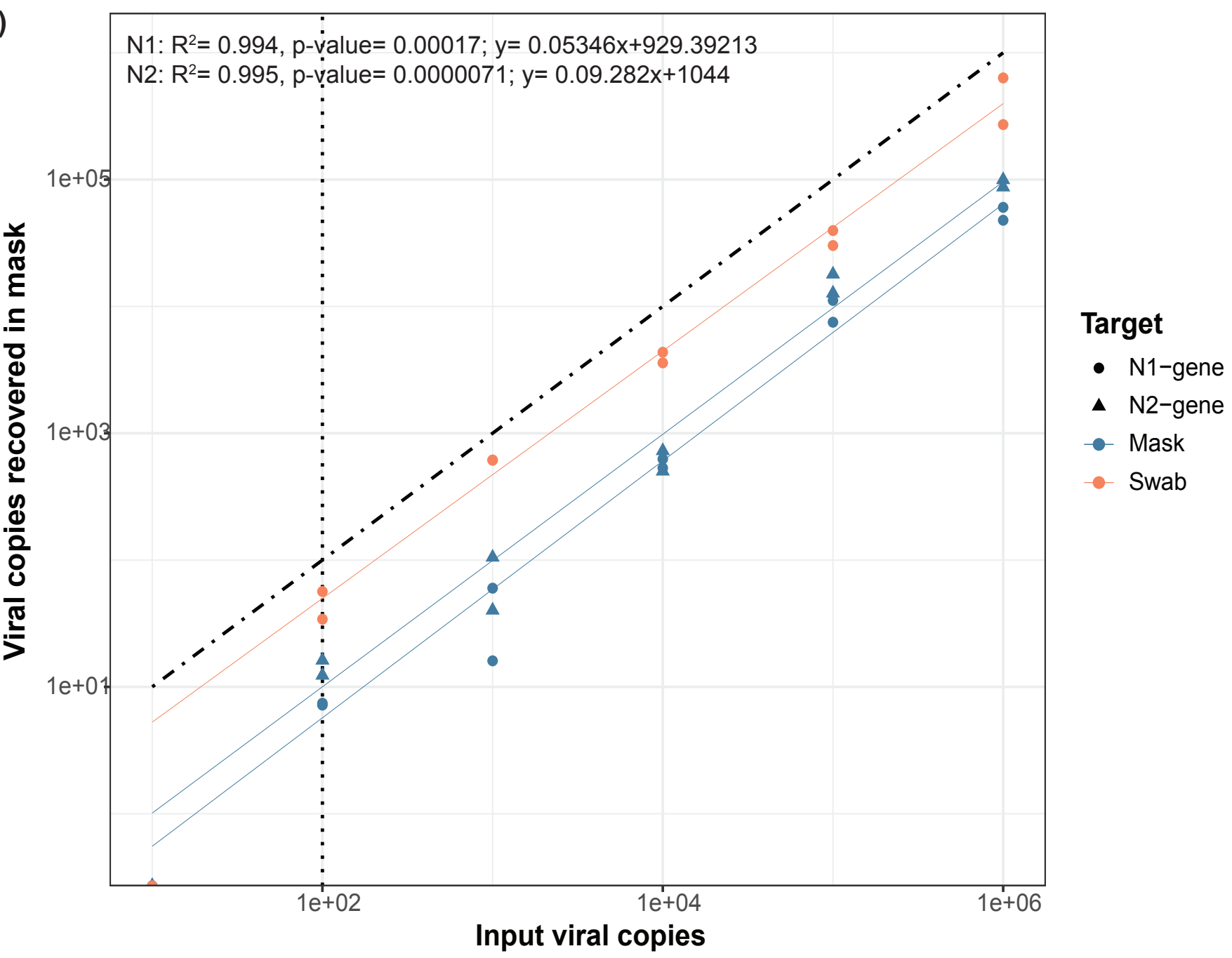

